\title{
Environmental education model in non-formal education at coastal community based on resilience and social ecological systems
}

\author{
Samadi Samadi ${ }^{1}$, and Dwi Sukanti Lestariningsih ${ }^{1}$ \\ ${ }^{1}$ Universitas Negeri Jakarta, Jakarta, Indonesia
}

\begin{abstract}
The study aims to identify factors for environmental education in non-formal education at coastal community, based on resilience and social-ecological systems as well as having the characteristics of marine until May-October 2014. This study used a qualitative approach, were involved in depth interview for key informant. This research was conducted in the coastal areas Cipatujah, Tasikmalaya regency of West Java Province. The results showed that the identification of factors that influence the construction of models of environmental education in the implementation of non-formal education in coastal communities are factors : (1) Strategy and Policy of Non -Formal PLH namely the carrying capacity of infrastructure and resources with the supporters as well as human resources sufficient education; (2) Carrying Capacity of Natural Resources and Environment Coastal Communities, namely the integration of ecological, sector integration and stakeholder alignment; (3) Cipatujah coastal communities need for infrastructure Grey mechanism involving roads, bridges, social infrastructure such as schools, health centers; and Blue infrastructure concerning infrastructure directly related to fishing activities such as fish auctions, boat docks, and shipbuilding. And lastly, (4) Efforts to develop and strengthen environmental education system in dire need of research location; based data systems business potential of marine and review of the supply side and demand side..
\end{abstract}

\section{Introduction}

Coastal environmental issues that are currently important to be resolved are the weak patterns of educational implementation for the community, especially the field of non-formal education. This problem, marked by the inclusion of strategic learning devices through environmental education materials in accordance with the character of the local community is very significant to the efforts of identification of environmental education factors mainly non-formal education in coastal communities based on resilience and socio-ecological system and has characteristics coastal and marine ecosystems.

The use of the coastal ecosystem has had an impact on the survival an area and other biota in the ecosystem. People's understanding of environmental education is still limited to be a constraint [1]. On the other hand, understanding is closely related to education levels; and lack of public understanding of the environment is indicated by the low behavior of a person who is shown by public concern for his or her environmental condition.

According to Raymond Boudon [2], in an effort to improve the quality of life and social welfare, residents in the coastal area need to be given an understanding of the value of responsibility to their environment in the form of good social interaction and the ability to overcome the risks due to social, economic, and political changes that surround it. Based on this phrase, there is clearly a deep gap between the efforts to save the coastal environment on the one hand, with the patterns of implementation of environmental education running.

In education process, the behavior of a person who is environmentally responsible can be shown from his environmentally friendly habits [3], a pattern of thinking that concerns environmental sustainability, a mindset that does not think about environmental sustainability, environmental sustainability motivation, and behavior of reusing goods. And simply, this behavior has a positive impact on the environment [4].

Education is essential in building social sensitivity towards the environment to develop a conservationaware citizen. According to Allaby [5], conservation is active management of the biosphere with purpose to maintain the sustainability of the maximum species biodiversity and maintain the genetic diversity within a certain species, including the maintenance of the biosphere's functions such as the ecosystem function and nutrient cycle. It can be said that conservation is regular maintenance and protection of something to prevent damage and extinction by preserving; preservation. From the two definitions above, it can be understood that conservation education is efforts to train students, both

\footnotetext{
*Corresponding author: samadi@unj.ac.id
} 
directly and indirectly, so that they have the sense to maintain and protect nature from damage and extinction.

And related problems above, usually found the fact that the lack of understanding of society to the environment is indicated by the bad behavior towards the environment and the lack of public awareness of each other to the environment [6]. The lack of public understanding of the environment is usually measured by the following parameters [7]: (1) Dynamics of biodiversity, (2) Redundancy (functional overlap) of the ecosystem, and (3) Spatial patterns of macro affecting the environment.

Within the social system, governance and environmental management frameworks can lead to environmental risks, so that if these problems occur, then diversification of resource use patterns and community lifestyle alternatives in utilizing resources should be able to maintain ecosystem services [8]. This is what gave rise to the term of social sensitivity in the framework of environmental response.

Social sensitivity, which has been defined as the ability to accurately perceive and comprehend the behavior, feelings and motives of other individuals, is generally viewed by personality theorists, social psychologists and clinicians a like to be a psychological variable of major importance for the understanding of such basic phenomena as the development of a conception of self, the acquisition of roles and the interaction within and between groups [9]. It can be defined as the condition of a student in a community group that understands, feels, and provides solutions for various social issues and phenomena around him / her.

The development of Hine [10] on causal models of hypotheses based on responsible environmental behavior developed explains that there are at least three related variables: (1) Effects on intention to act, (2) Locus of control and attitude more important than knowledge, and (3) Personal responsibility. More specifically, these findings indicate that in order to promote responsible environmental behavior, the environmental education and interpretation systems need to focus on changes occurring in the internal locus of control.

Locus of control according to Rotter [11] is an action in which individuals relate events in their life to actions or forces beyond their control. Locus of control is a concept that refers to individual beliefs about events occurring in life. Locus of control illustrates how far a person views the relationship between an action done with an outcome. Locus of control relates to the characteristics / attitudes and work attitude of a person both internally and externally [12]. This study aims to identify the factors of environmental education, especially in the implementation of non-formal education in coastal communities, based on the resilience and socio-ecological system and has marine characteristics.

\section{Methodology}

This research use a mix method, were involved in depth interview for key informant. This research was conducted in the coastal areas Cipatujah, Tasikmalaya regency of West Java Province. The location of the study was at $7^{\circ} .732584$ South, 108.029369 East.

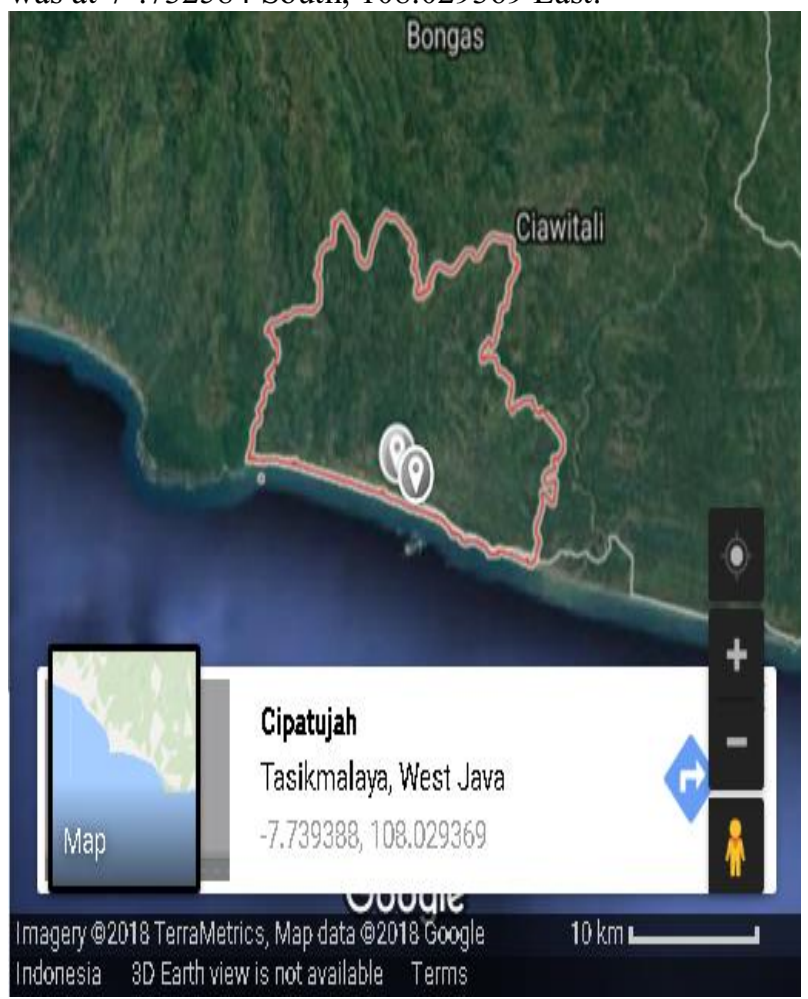

Fig. 1. Location of the study.

\section{Results and discussion}

\subsection{Identification of environmental education strategy and policy}

In the process of achieving the strategies and policies of non-formal environmental education, it is necessary to have integrated information related to the condition of the carrying capacity of infrastructure and supporting resources. Related to the condition of the carrying capacity of infrastructure, should be supported by the ability of human resources, especially the power level of education in addition to the ability to use the advancement of knowledge and technology. The supporting resources are very important role also in the model construction process in this study are financial factors.

Specifically, Archibald P. Sia, Harold R. Hungerford and Audrey N. Tomera [13], outlined eight relative contributions in predicting responsible environmental behavior. Seven of the eight variables found to be statistically significant are: (1) Environmental sensitivity level, (2) perceived knowledge of environmental action strategies, (3) perceived skills in using environmental action strategies, (4) classification of the role of psychological sex, (5) Individual focus control, (6) Locus of control group, and (7) Attitudes towards pollution. While the significant variables are (8) Confidence in technology. 


\subsection{Supporting capacity of natural resources and environment of coastal communities}

In the formulation of management policies, an approach that can be applied optimally and sustainably is required. Therefore, the management approach that is carried out can't be separated from the approach of management with a bigger scope, namely the approach of coastal and ocean area management through integrated approach.

\subsubsection{Ecological integration}

Ecologically, coastal and marine resources have linkages between land (land) and coastal areas. Therefore, the management of coastal resources can not be separated from the environmental management carried out in both areas of the region. The impacts of environmental damage that disrupt the balance and presence of coastal resources and marine biodiversity are largely due to the impacts of development activities on the upper land, such as agriculture, plantations, forestry, industry, settlements and so on, in addition to activities carried out at the sea freely itself, such as sea transportation activities, sand mining and so on.

This condition results in a good ecological social endurance, as previously described by Anderies JM, MA Janssen and E Ostrom; that socio-ecological resilience is a system of biological / ecosystem units connected with and influenced by one or more social systems, in the sense of forming cooperative and interdependent relationships with others [14].

Handling pollution caused by industry and household waste, sedimentation, and waste can not only be done in the seagrass area alone, but also should be done from the source of the impact. Therefore, the management of the seagrass environment should be integrated with the land and coastal areas and water systems in order to become a unity and integrated management. Management of the good Cipatujah Bay area will be destroyed in an instant if it is not balanced with good watershed planning as well. The linkage between ecosystems must always be considered, considering the mangrove ecosystem, seagrass and coral reefs are unity of interconnected ecosystems with the diversity of roles and functions owned by each ecosystem.

\subsubsection{Sectoral integration}

This sectoral integration, including horizontal integration (inter sector) and vertical integration (in one sector). Therefore, spatial arrangement and guidance on development and management of resources is necessary to avoid conflict between one activity with other activities.

The context of sectoral integration discussed from the results of this study refers to the capacity of communities, social institutions or social communities associated with managing coastal ecosystems to survive and be able to cope with change due to various social and economic activities [15].

\subsubsection{The integration of stakeholders}

All of the above alignment, will be successfully implemented if supported by the integration of the perpetrators of the utilization and management of coastal and ocean resources. As is known that the perpetrators of the utilization and management of coastal and marine resources, among others, consists of government (central and local), coastal communities, private (investors) and also non-governmental organizations which each have an interest in the utilization of natural resources. The development management plan should use a twopronged approach, top down approach and bottom up approach. This can be seen in the issue of integration to relevant stakeholders, where responsible responsible behavior refers to the action of individuals or groups directed to find the best solution of environmental problems [16].

\subsection{Response to the condition of coastal and marine ecosystems}

In general, responses made by respondents to coastal and marine conditions show that almost all respondents make a response to create a group of fishermen, catching further from the existing conditions due to declining resources, then make environmental improvements, although this is only a hope that has not followed by real actions of their own, but at least these hopes became the policy directives for the local government. Almost all respondents stated the need to preserve the coastal and marine environment for their marine business continuity, because they are aware that the pollution of the water environment can not be tolerated anymore. It is characterized by a combination of self-interest and concern for others, species, or ecosystems; including talking with others about environmental issues, encouraging families and friends to behave in a responsible way to the environment [17].

\subsection{Needs and wants analysis of non-formal education program}

From observations, field interviews and Focus Group Discussion with stakeholders, "necessary condition" for the sustainability of capture fisheries is the need for marine fishery infrastructure, especially for areas that are relatively difficult to reach such markets in the South coast. This infrastructure can be divided into two things: "Gray infrastructure" and "Blue infrastructure". Gray infrastructure is a common infrastructure that can disrupt marine fisheries activities, such as roads, bridges, social infrastructure (schools, puskesmas, etc.), while Blue infrastructures are directly related to fishery activities such as fish auctions, boat docks, shipbuilding, and etc.

The analysis of the list of needs and desires can be seen from factors such as intent to act, prior knowledge of problems encountered, and the desire to act more likely to lead to the actual action of the individual [18]. 


\subsection{The model's}

\begin{tabular}{|c|c|}
\hline $\begin{array}{c}\text { Resilience } \\
\text { and Social } \\
\begin{array}{c}\text { Ecological } \\
\text { Systems }\end{array}\end{array}$ & $\begin{array}{c}\text { Carrying Capacity of Natural Resources and } \\
\text { Environment Coastal Communities : } \\
\text { integration of ecological, sector integration and } \\
\text { stakeholder alignment }\end{array}$ \\
\hline develop and strengthen environmental education system \\
\hline $\begin{array}{c}\text { infrastructure support and human } \\
\text { resources improvement }\end{array}$ \\
need for Grey infrastructure and Blue infrastructure \\
\hline
\end{tabular}

Fig. 2. Environmental Education Model in Non Formal Education at Coastal Community based on Resilience and Social Ecological Systems.

\section{Conclusions}

The conclusion of this research are : (1) Strategy and Policy of Non-Formal Education namely the carrying capacity of infrastructure and resources with the supporters as well as human resources sufficient education; (2) Carrying Capacity of Natural Resources and Environment Coastal Communities, namely the integration of ecological, sector integration and stakeholder alignment; (3) Cipatujah coastal communities need for Grey infrastructure that's mechanism involving roads, bridges, social infrastructure such as schools, health centers; and Blue infrastructure concerning infrastructure directly related to fishing activities such as fish auctions, boat docks, and shipbuilding. And lastly, (4) Efforts to develop and strengthen environmental education system in dire need of research location; based data systems business potential of marine and review of supply side and demand side.

\section{References}

1. Samadi, Warnadi, Asma 'Irma Setyaningsih, Wiwin Anggara Kasih. Water Quality and It's Effect on Seaweed Cultivation in Pari Island, Kepulauan Seribu DKI Jakarta. IGEOS International Conference, Bandung. (2017)

2. Raymond Boudon. Theories of Social Change, p.166-173. (Polity Press, Cambridge UK 1986)

3. Bechtel R. dan Churchman A. Handbook of Environmental Psychology. p.259. (John Wiley \& Sons, Inc., New York, 2002).

4. Dunlap, Measuring Endorsement of the New Ecological Paradigm. J of Social Issues. 56:3, p.425-442. (2000).

5. Allaby, M. Oxford Dictionary of Plant Sciences. Revised Edition. (Oxford University Press, United States, 2007)

6. Garrod, B. dan Wilson J. Aspects of Tourism: Marine Ecotourism Issues and Experiences. Channel View Publications. p.187-189. (2001)
7. W. Neil Adger, Terry P. Hughes, Carl Folke, Stephen R. Carpenter, Johan Rockström. J of Science 12 Aug Vol. 309, Issue 5737, pp. 10361039. (2005)

8. R. Costanza, M. Daly, C. Folke, P. Hawken, CS. Holling, AJ. McMichael, D. Pimentel, D. Rapport. Managing Our Environmental portofolio. J of BIOSCIENCE. Volume: 50. Issue: 2. P.s: 149-155. (2000)

9. Barbara B. Rothenberg. Children's Social Sensitivity and The Relationship to Interpersonal Competence, Intrapersonal Comfort and Intellectual Level. ETS Research Bulletin Series, Volume 1968, Issue 1, Version of Record online: 8 AUG 2014. (2014)

10. Yeong-Hyeon Hwang, Seong-Il Kim and JiannMin Jeng. Examining the Causal Relationships Among Selected Antecedents of Responsible Environmental Behavior. The J of Environmental Education, Volume 31, Issue 4, (2000)

11. J. B. Rotter. Generalized expectancies for internal versus external control of reinforcement. J of Psychological Monographs, 80 (1, Whole No. 609). (1996)

12. J. B. Rotter. Internal Versus External Control of Reinforcement: A Case History of a Variable. J of American Psychologist, April, pp.490-493. (1990)

13. Archibald P. Sia, Harold R. Hungerford \& Audrey N. Tomera. Selected Predictors of Responsible Environmental Behavior: An Analysis. The Journal of Environmental Education, Volume 17 Issue 2. (1986)

14. Anderies JM, MA Janssen \& E Ostrom. A Framework to Analyze The Robustness of SocialEcological Systems from An Institutional Perspective. J of Ecology and Society, 9 (1), 18. (2004)

15. Markus Keck and Patrick Sakdapolrak. What is Social Resilience? Lessons Learned and Ways Forward. J of Erdkunde, Vol.67-No.1. (2013)

16. Sivek, D. J., and Hungerford, H. Predictors of responsible behavior in three Wisconsin conservation organizations. The J of Environmental Education, 17(2), pp.31-40. (1989)

17. Bamberg, S., and Moser, G., Twenty years after Hines, Hungerford, and Tomera: A new metaanalysis and psycho-social determinants of proenvironmental behavior. $\mathrm{J}$ of Environmental Psychology, 27. pp.14-25. (2007)

18. H. R. Hungerford and T. L. Volk. Changing learning behavior through environmental education. $\mathrm{J}$ of Environmental Education, 21(3), pp.8-21. (1990) 